\title{
A new 3,4-dihydroxypyrrolidine-based material for molecular recognition
}

\author{
Stefano Cicchi, Valentina Paschetta, and Alberto Brandi* \\ Università degli Studi di Firenze, Dipartimento di Chimica Organica "Ugo Schiff” \\ Polo Scientifico, via della Lastruccia 13, I-50019, Sesto Fiorentino, Firenze, Italy \\ E-mail: alberto.brandi@unifi.it
}

Dedicated to Professor Branko Stanovnik on his $65^{\text {th }}$ anniversary

(received 05 Aug 03; accepted 01 Oct 03; published on the web 17 Oct 03)

\begin{abstract}
The synthesis of a new pseudopeptide material based on a chiral pyrrolidine skeleton is described. One of these new compounds interacts, in chloroform solution, selectively with amines.
\end{abstract}

Keywords: Pyrrolidine, molecular recognition, amino acid, $C_{3}$ symmetry

\section{Introduction}

Molecular recognition phenomena are the basis of any biological process and extensive effort has been spent to understand the mechanism of such processes and to discover new examples and applications. Since large part of recognition processes, particularly those in biological systems, are based on the formation of hydrogen bonds between host and guest molecules, ${ }^{1}$ most effort are devoted to the construction of a host abundant of hydrogen bond donating groups as , aminoacids, carbohydrates units and sulfonamides. ${ }^{2}$ One direction chosen by researcher on the way to build up a synthetic enzyme, consists of the selection of scaffold onto which easily accessible optically pure units, containing elements necessary for recognition, are implemented. $^{2,3}$ Trimesic acid (benzene-1,3,5-tricarboxylic acid) has been often used as a rigid scaffold for the grafting of proper substituents and, recently, it has been demonstrated that amide derivatives of trimesic acid can adopt, in the solid phase, a bell shaped arrangement with the three carbonyl group pointing towards the same side of the aromatic ring. ${ }^{4}$ Such arrangement give rise to a cavity that could host small molecules properly substituted. ${ }^{5}$ The potential for application in molecular recognition processes is evident. Along this track we propose now a new material 1 (figure 1) based on a pseudo peptidic branch, built up around a $C_{2}$ symmetric pyrrolidine skeleton, implemented in a rigid frame of trimesic acid. In this article the synthesis 
of three derivatives, compounds 1a-c, characterized by the presence of three different aminoacids, as well as the application of compound 1a to the selective recognition of amines are described.

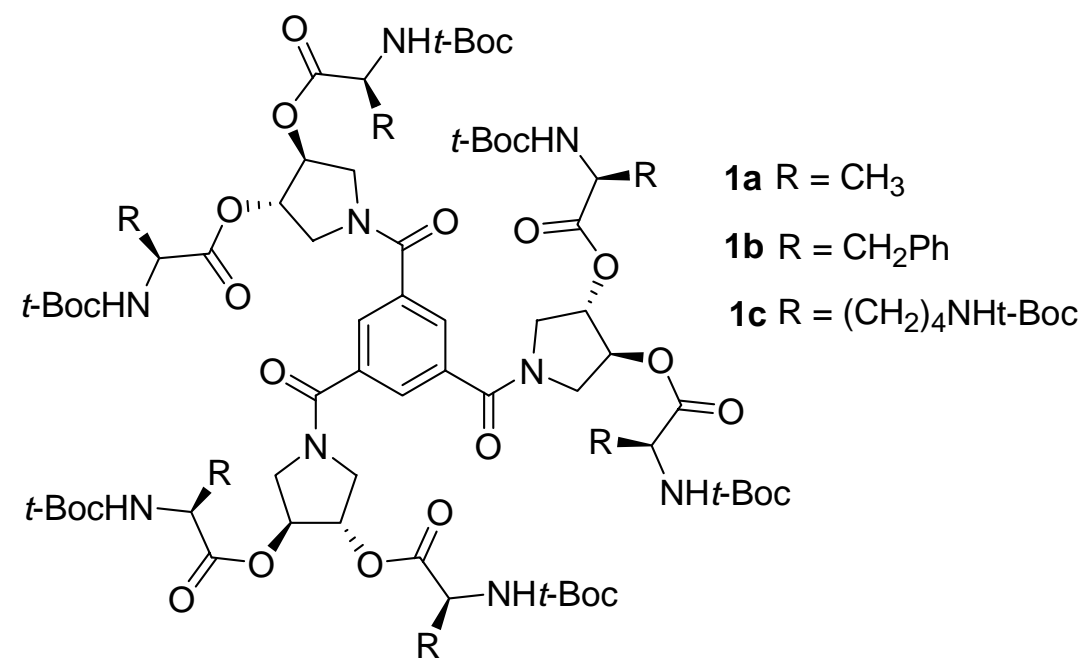

Figure 1

\section{Results and Discussion}

The synthesis of 1a-c was devised in a convergent way, i.e. by the synthesis of branches that are inserted in the central scaffold. The approach is suitable for further application in combinatoriallike synthesis.
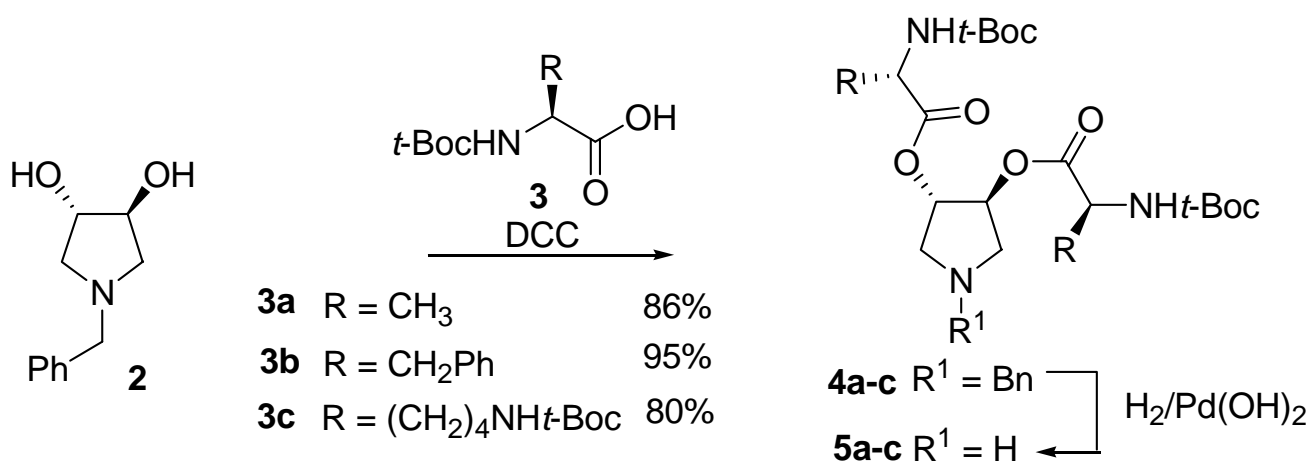

\section{Scheme 1}

The branches 4a-c were easily synthesized in high yield by dicyclohexylcarbodiimide (DCC) mediated coupling of protected aminoacids, 3, with $(3 S, 4 S)-N$-benzyl-3,4-dihydroxypyrrolidine (2) (scheme 1). The $C_{2}$ symmetry of these derivatives is reflected into their ${ }^{1} \mathrm{H}$ and ${ }^{13} \mathrm{C}$ NMR 
spectra. The two aminoacidic residues are equivalent as well as the two methyne and methylene groups of the pyrrolidine ring. Reductive debenzylation of 4a-c afforded in quantitative yields compounds 5a-c (scheme 1). Reaction of pyrrolidines 5a-c with benzene-1,3,5-tricarbonyl chloride afforded compound 1a-c in 57\%, 40\% and 57\% yield respectively.

Again the overall $C_{3}$ symmetry of compounds 1a-c is confirmed by the simple ${ }^{1} \mathrm{H}$ and ${ }^{13} \mathrm{C}$ NMR spectra of these compounds. The spectra of compound 1a are representative of all three compounds. Concerning the ${ }^{1} \mathrm{H}$ NMR spectrum, compound 1a showed a single resonance at 7.89 ppm for the three equivalent protons of the central aromatic ring. The amide moieties that link the pyrrolidine rings to the core hamper the free rotation along the $\mathrm{N}-\mathrm{C}$ bond disrupting the $C_{2}$ simmetry of the two substituents of the branches and the $\mathrm{H} 3$ and $\mathrm{H} 4$ of each pyrrolidine ring resonate as separate signals giving rise to a multiplet at $5.24 \mathrm{ppm}$. Nevertheless the three groups grafted onto the central aromatic ring result equivalent. Also the ${ }^{13} \mathrm{C}$ NMR spectrum confirmed the absence of $C_{2}$ simmetry for each pyrrolidine nucleus (different signal for the two methylene groups at 52.4 and $50.5 \mathrm{ppm}$ ) but the equivalence of the three branches.

Tertiary aromatic amides are not planar for steric reasons. In tertiary benzamides steric hindrance surrenders to conjugation when the amide is twisted at an angle $57^{\circ}$ to the ring. ${ }^{6}$ For this reason the three group grafted around the aromatic core of trimesic acid do not lie in the same plane but stretch out in space with the possibility to build a network of hydrogen bonds that could give rise to a bell shaped structure in solution. ${ }^{7}$

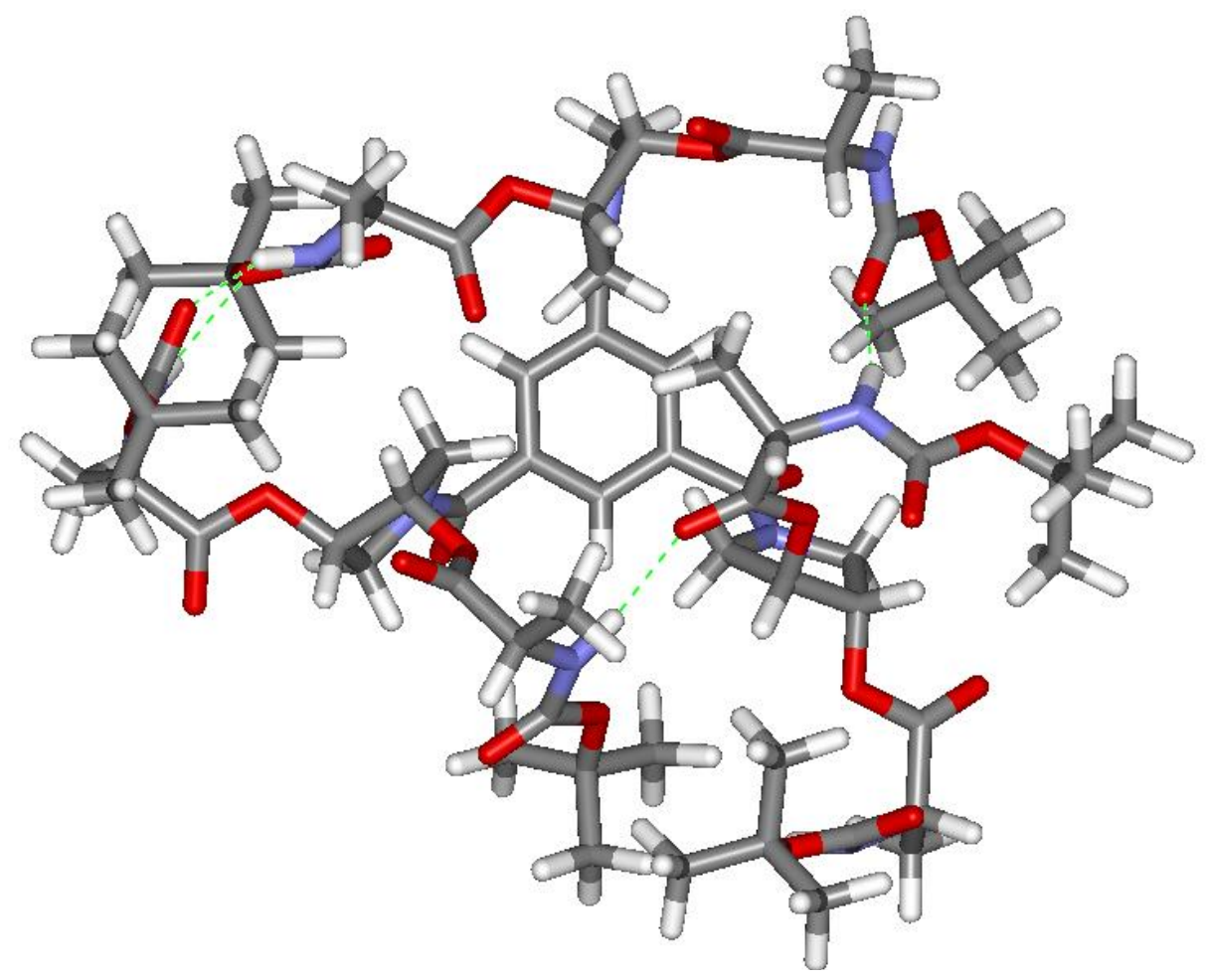

Figure 2. Minimum energy conformationfor compound 1a. 
The result of a molecular mechanics study (Monte Carlo method, Force field MMFF94, 7744 cycles $)^{8}$ on a model compound showed that the minimum energy conformation is the one depicted in figure 2. This bell shaped conformation is stabilized by four hydrogen bond which link together the three branches of the molecule.

Compound 1a-c do not self-aggregate in solution as it is shown by ${ }^{1} \mathrm{H}$ NMR spectroscopy: no variation of chemical shift was evidenced recording spectra at increasing concentration from $10^{-3}$ to $10^{-1} \mathrm{M}$ in $\mathrm{CDCl}_{3}$. A FT-IR analysis for compound 1a did not confirm definitely the presence of intramolecular hydrogen bonds in chloroform. However the spectrum at dilute $\left(10^{-3} \mathrm{M}\right)$ concentration presented two slightly defined NH bands at 3450 and $3440 \mathrm{~cm}^{-1}$ that collapsed in a single broader resonance at $3440 \mathrm{~cm}^{-1}$ by increasing the concentration to $10^{-2} \mathrm{M}$ due to intra and intermolecular hydrogen bonding.

To verify the possibility of molecular recognition towards substrates prone to form hydrogen bond interactions we registered ${ }^{1} \mathrm{H}$ NMR spectra of $1: 1$ mixtures of hosts 1a-c and various structurally differentiated guests. A marked variation (at least $0.2 \mathrm{ppm}$ ) in chemical shift of any signal was considered to indicate an interaction worthwhile to be deeper analysed.

Compound 1a revealed to interact with amines, aminoalcohols and, to a lower extent, with primary and secondary amides while no interaction was evidenced with carboxylic acids, ammonium salt, carboxylates, alcohols and tertiary amides. Compounds $\mathbf{1 b}-\mathbf{c}$ did not show any appreciable interaction towards any of these substrates. A deeper analysis was performed to quantify the interaction of 1a towards piperidine for which the strongest interaction was evidenced (shift of $1 \mathrm{ppm}$ for the NH proton at 1:1 piperidine/1a ratio). In figure 3 is reported the titration curve of piperidine (NH signal) with $1 \mathbf{1 a}$.

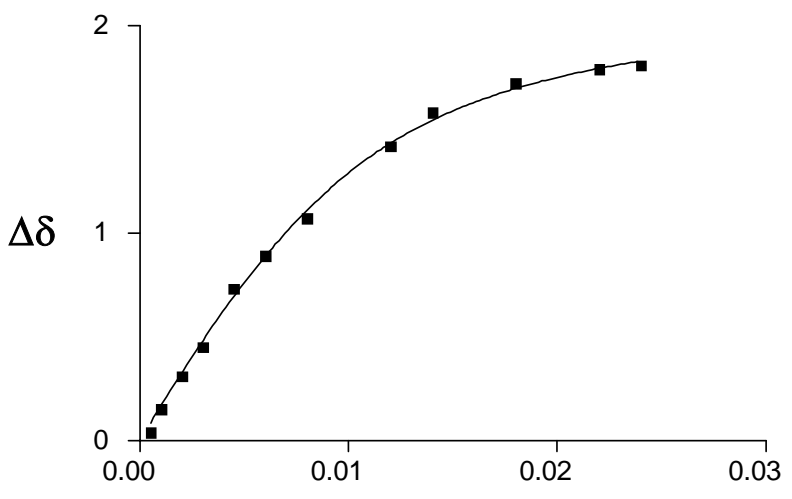

[1a]

Figure 3. Titration curve of piperidine with 1 a.

The graphic shown in figure 2 indicates the saturation obtained increasing the concentration of host $1 \mathrm{a}$ from $5 \times 10^{-4}$ to $2.4 \times 10^{-2} \mathrm{M}$. The non-linear regression analysis data for titration of piperidine indicated a $\mathrm{K}_{\mathrm{ass}}=380 \pm 80 \mathrm{M}^{-1}$ together with a $\delta_{\infty}=2.14 \mathrm{ppm}^{9}$ 
A Job plot, showing a maximum at 0.5 for the system piperidine-1a confirms a $1: 1$ interaction between the two molecules (Figure 4). ${ }^{10}$

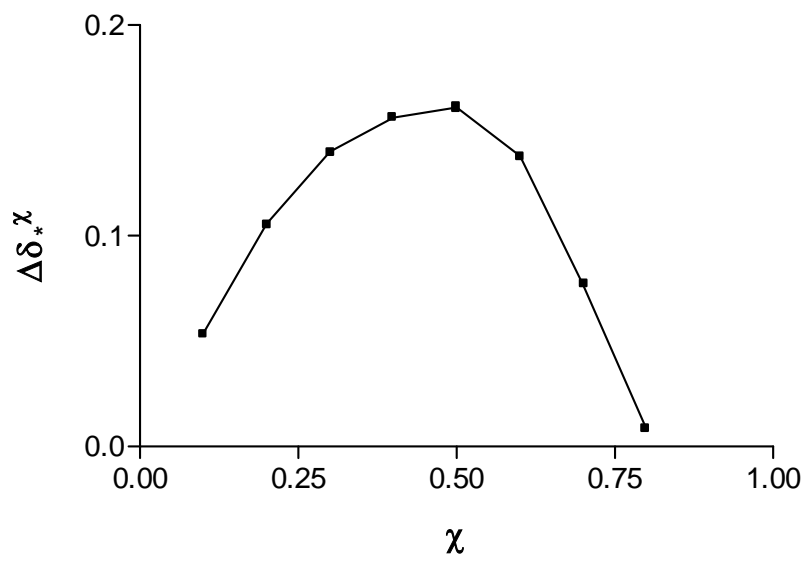

Figure 4. Job plot for the system piperidine-1a.

To verify if the presence of three group grafted onto the aromatic ring is crucial for the recognition process, the complexation ability of $1 \mathbf{a}$ was compared with that of compounds $\mathbf{6}$ and 7, similar to 1a, but lacking of its $C_{3}$ symmetry. Compounds 6 and 7 were obtained through reaction of 5 with benzoyl and terephtaloyl chloride respectively (figure 5). None of the substrates screened with 1a showed an interaction with 6 and 7, even increasing the concentration of the host, ruling out also the possible acid-base reaction between piperidine and compound 1a.
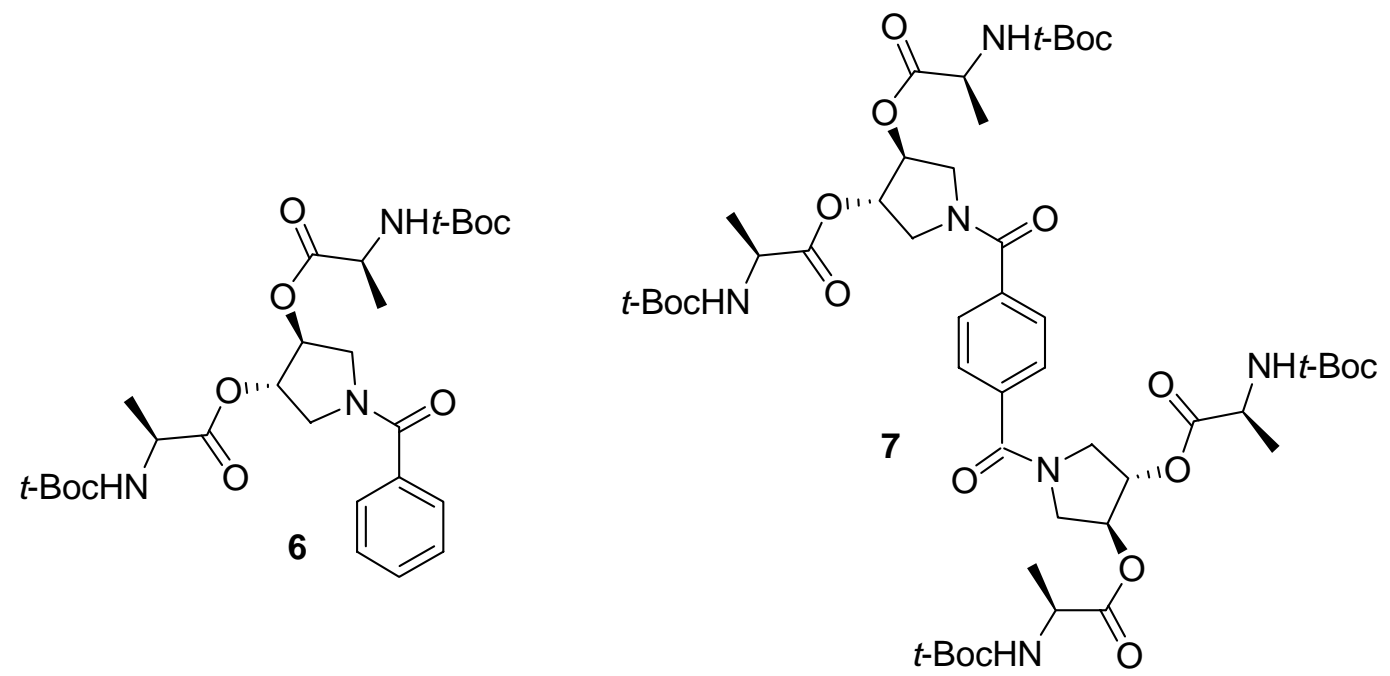

\section{Figure 5}


The $C_{3}$ symmetry of compound 1a, therefore, must induce an appropriate arrangement of hydrogen bond donating groups which lacks in compounds 6 and 7, unable to interact with any substrates, and reveals essential to build up the complexation. Such arrangement might be described on the basis of the structure depicted in Figure 2. The selectivity observed and the 1:1 interaction between piperidine and compound 1a must derive, therefore, from a positive balance between attractive and repulsive interactions. Steric factors are probably responsible for the absence of interactions found between amines and 1b or 1c. A molecular mechanic study, in analogy to what reported for 1a, showed that the presence of substituents bulkier than Me on the aminoacidic residue hampers the formation of the bell shape conformation. In conclusion we have described the synthesis of a new compound characterised by an overall $C_{3}$ symmetry and by six terminal aminoacidic residues which showed selective complexing ability towards amines, aminoalcohols and, to a minor extent, amides. The extension of the synthetic procedure to obtain combinatorial libraries of these compounds and dendrimeric derivatives is currently ongoing in our laboratories, as well as experiments to gain a deeper insight in the interaction process.

\section{Experimental Section}

General Procedures. All operations were carried out under inert gas and with anhydrous solvents where required. Rf values refer to TLC on $0.25 \mathrm{~mm}$ silica gel plates (Merck F254) with the same eluent used for the chromatographic separation of compounds. ${ }^{1} \mathrm{H}$ and ${ }^{13} \mathrm{C}$ NMR spectra (in $\mathrm{CDCl}_{3}$ solution) were recorded at $200 \mathrm{MHz}$ and $50 \mathrm{MHz}$ respectively, with a Varian Gemini; the chemical shifts for ${ }^{1} \mathrm{H}$ and ${ }^{13} \mathrm{C}$ NMR spectra are given in ppm from TMS. IR spectra were recorded with a Perkin-Elmer 881 spectrophotometer. Optical rotation measurements were carried out with a Jasco DIP-370 polarimeter.

\section{General procedure of synthesis of diesters 4a-c}

A solution of $375 \mathrm{mg}(1.94 \mathrm{mmol})$ of pyrrolidine 2 in $30 \mathrm{ml}$ of anydrous $\mathrm{CH}_{2} \mathrm{Cl}_{2}$ at room temperature and under nitrogen atmosphere, was added with an $N$ - $t$-Boc protected aminoacid (alanine 3a, phenyl alanine $3 \mathbf{b}$ and lysine 3c) $(3.88 \mathrm{mmol})$ and DMAP (20 mg, $0.16 \mathrm{mmol})$. The solution was then added with DCC ( $825 \mathrm{mg}, 4 \mathrm{mmol})$ and stirred for $24 \mathrm{~h}$. The final suspension was filtered and the solution concentrated to afford the crude reaction mixture which was purified by flash column chromatography.

Diester (4a). 86\% yield. $\mathrm{R}_{\mathrm{f}}$ (ethyl acetate, petroleum ether $\left.1: 2\right)=0.43$. $[\alpha]_{\mathrm{D}}{ }^{20}=15.5(\mathrm{c}=1.11$, $\left.\mathrm{CHCl}_{3}\right)$. IR $\left(\mathrm{CHCl}_{3}\right): 3440,2981,1741,1709,1602,1155 \mathrm{~cm}^{-1} .{ }^{1} \mathrm{H} \mathrm{NMR}\left(\mathrm{CDCl}_{3}\right): 7.30(\mathrm{~m}, 5 \mathrm{H})$, 5.14 (bs, 2H, CHO), $4.92(\mathrm{~m}, 2 \mathrm{H}), 4.28\left(\mathrm{~m}, 2 \mathrm{H}, \mathrm{CH}-\mathrm{CH}_{3}\right), 3.65$ (AB system, $\left.2 \mathrm{H},-\mathrm{CH}_{2}-\mathrm{Ph}\right), 3.05$ $(\mathrm{dd}, J=10.6,6.3 \mathrm{~Hz}, 2 \mathrm{H}, \mathrm{NCHH}), 2.59$ (dd, $J=10.6,4.4 \mathrm{~Hz}, 2 \mathrm{H}, \mathrm{NCHH}), 1.42$ (s, 18H, C$\left.\left(\mathrm{CH}_{3}\right)_{3}\right), 1.38\left(\mathrm{~d}, J=7.3 \mathrm{~Hz}, 6 \mathrm{H}, \mathrm{CH}-\mathrm{CH}_{3}\right) .{ }^{13} \mathrm{C} \mathrm{NMR}\left(\mathrm{CDCl}_{3}\right): 172.8$ (s), 155.0 (s), 138.2 (s), 128.8 (d), 128.1 (d), 127.1 (d), 80.1 (s), 78.5 (d), 59.5 (t), 57.8 (t), 49.2 (d), 28.8 (q), 18.5 (q). Anal calcd. for $\mathrm{C}_{27} \mathrm{H}_{41} \mathrm{~N}_{3} \mathrm{O}_{8}$ (535.64): C 60.54, H 7.71, N 7.84. Found C 60.59, H 7.72, N 7.52\%. 
Diester (4b). $95 \%$ yield. $\mathrm{R}_{\mathrm{f}}\left(\mathrm{CH}_{2} \mathrm{Cl}_{2}, \mathrm{MeOH} 20: 1\right)=0.81 .[\alpha]_{\mathrm{D}}{ }^{20}=46.0$ (c = 1.05, $\left.\mathrm{CHCl}_{3}\right)$. IR $\left(\mathrm{CHCl}_{3}\right): 3439,2978,1706,1156 \mathrm{~cm}^{-1} .{ }^{1} \mathrm{H} \mathrm{NMR}\left(\mathrm{CDCl}_{3}\right): 7.30$ (m, 10H, Ph), 7.17 (m, 5H, Ph), $5.00(\mathrm{~m}, 4 \mathrm{H}, \mathrm{CHO}-$ and $\mathrm{N}-\mathrm{H}), 4.58(\mathrm{~m}, 2 \mathrm{H}, \mathrm{CH}-\mathrm{Bn}), 3.58$ (AB system, 2H, N-CH $-\mathrm{Ph}), 3.08$ (m, $\left.2 \mathrm{H}, \mathrm{CH}-\mathrm{CH}_{2}-\mathrm{Ph}\right), 2.90(\mathrm{dd}, J=10.6,6.6 \mathrm{~Hz}, 2 \mathrm{H}, \mathrm{NCHH}), 2.48(\mathrm{dd}, J=10.6,3.7 \mathrm{~Hz}, 2 \mathrm{H}$, $\mathrm{NCHH}), 1.43$ (s, 18H, C- $\left.\left(\mathrm{CH}_{3}\right)_{3}\right) .{ }^{13} \mathrm{C} \mathrm{NMR}\left(\mathrm{CDCl}_{3}\right): 171.2$ (s), 155.0 (s), 137.6 (s), 135.9 (s), 129.4 (d), 128.8 (d), 128.6 (d), 128.4 (d), 127.3 (d), 127.1 (d), 79.9 (s, C-(CH$\left.)_{3}\right), 77.7(\mathrm{~d}, \mathrm{CHO})$, $59.5(\mathrm{t}), 57.8$ (t), 54.3 (d), 38.3 (t), 28.26 (q). Anal. Calcd. for $\mathrm{C}_{39} \mathrm{H}_{49} \mathrm{~N}_{3} \mathrm{O}_{8}$ (687.83): C 68.10, $\mathrm{H}$ 7.18, N 6.11. Found C 68.02, H 7.45, N 6.38\%.

Diester (4c). $80 \%$ yield. $\mathrm{R}_{\mathrm{f}}$ (ethyl acetate, petroleum ether $\left.1: 1\right)=0.58 .[\alpha]_{\mathrm{D}}{ }^{20}=5.5(\mathrm{c}=1.06$, $\left.\mathrm{CHCl}_{3}\right)$. IR $\left(\mathrm{CHCl}_{3}\right): 3447,2977,1707,1594,1158 \mathrm{~cm}^{-1} .{ }^{1} \mathrm{H} \mathrm{NMR}\left(\mathrm{CDCl}_{3}\right): 7.29$ (m, 5H, $\left.\mathrm{Ph}\right)$, $5.11(\mathrm{~m}, 4 \mathrm{H}, \mathrm{CHO}-$ and N-H), $4.89(\mathrm{~m}, 2 \mathrm{H}, \mathrm{N}-\mathrm{H}), 4.25$ (m, 2H, C-CH-NH), 3.60 (AB system, 2H, $\left.\mathrm{CH}_{2}-\mathrm{Ph}\right), 3.12$ (m, 6H, CHH-NBn and $\left.\mathrm{CH}_{2}-\mathrm{N}\right), 2.59$ (m, 2H, CHH- NBn), 1.74 (m, 7H, $\left.(\mathrm{CH})_{2}\right)^{-}, 1.42\left(\mathrm{~s}, 18 \mathrm{H}, \mathrm{C}-\left(\mathrm{CH}_{3}\right)_{3}\right), 1.40\left(\mathrm{~s}, 18 \mathrm{H}, \mathrm{C}-\left(\mathrm{CH}_{3}\right)_{3}\right) 1.40\left(\mathrm{~m}, 5 \mathrm{H},(\mathrm{CH})_{2}\right) .{ }^{13} \mathrm{C} \mathrm{NMR}$ $\left(\mathrm{CDCl}_{3}\right): 172.3$ (s), 155.9 (s), 137.3 (s), 128.7 (d), 128.3 (d), 127.3 (d), 79.9 (d), 79.1 (d), 78.5 $(\mathrm{s}), 59.5(\mathrm{t}), 57.86(\mathrm{t}), 53.27(\mathrm{~d}), 40.15(\mathrm{t}), 32.03(\mathrm{t}), 29.4(\mathrm{t}), 28.5(\mathrm{q}), 28.36(\mathrm{q}), 22.5(\mathrm{t})$. Anal. calcd. for $\mathrm{C}_{43} \mathrm{H}_{71} \mathrm{~N}_{5} \mathrm{O}_{12}$ (850.06): C 60.76, H 8.42, N 8.24. Found C 60.88, H 8.41, N 7.91.

\section{General procedures of reductive debenzylation of diesters 4a-c}

A solution of the diester $(1 \mathrm{mmol})$ in $\mathrm{MeOH}(5 \mathrm{~mL})$ was added with $100 \mathrm{mg}$ of $20 \% \mathrm{Pd}(\mathrm{OH})_{2} / \mathrm{C}$ and the resulting suspension was stirred under $\mathrm{H}_{2}$ atmosphere for $12 \mathrm{~h}$. The suspension was then filtered and the solution concentrated to afford the crude secondary amine in quantitative yield. The crude amines were immediately used without futher purification.

\section{General procedures of synthesis of triamides of trimesic acid 1a-c}

A solution of the amine $5(1 \mathrm{mmol})$ in dry $\mathrm{CH}_{2} \mathrm{Cl}_{2}(12 \mathrm{~mL})$ was added with DMAP $(20 \mathrm{mg}, 0.16$ mmol) and DIPEA (1.06 mL, $6 \mathrm{mmol})$. The solution was cooled in an ice bath and added with benzene-1,3,5-tricarbonyl chloride $(87 \mathrm{mg}, 0.33 \mathrm{mmol}, 1 \mathrm{eq})$. The solution was stirred under inert atmosphere for $2 \mathrm{~h}$. The solution was then diluted with $\mathrm{CH}_{2} \mathrm{Cl}_{2}(50 \mathrm{~mL})$ and washed with $0.5 \mathrm{M} \mathrm{HCl}$, saturated $\mathrm{NaHCO}_{3}$ and finally with brine. The organic phase was dried with $\mathrm{Na}_{2} \mathrm{SO}_{4}$ and concentrated to afford the crude reaction mixture which was purified by passage on a short pad of silica gel.

Triamide (1a). 57\% yield. $\mathrm{R}_{\mathrm{f}}$ ( ethyl acetate, petroleum ether 5:1 ) $=0.52$. $[\alpha]_{\mathrm{D}}{ }^{20}=-30.1(\mathrm{c}=$ 1.00, $\left.\mathrm{CHCl}_{3}\right)$. IR $\left(\mathrm{CHCl}_{3}\right): 3442,2980,1751,1708,1636,1153 \mathrm{~cm}^{-1} .{ }^{1} \mathrm{H} \mathrm{NMR}\left(\mathrm{CDCl}_{3}\right): 7.89$ (s, $3 \mathrm{H}$, central core $\mathrm{H}), 5.24$ (m, 6H, CHO-), $5.09(\mathrm{~m}, 6 \mathrm{H}, \mathrm{N}-\mathrm{H}), 4.25\left(\mathrm{~m}, 6 \mathrm{H}, \mathrm{H}-\mathrm{C}-\mathrm{CH}_{3}\right), 4.0$ (m, 6H, H-CH-N), 3.8 (d, J = 11.9 Hz, 3H, H-CH-N), 3.6 (d, J = $11.9 \mathrm{~Hz}, 3 \mathrm{H}, H-\mathrm{CH}-\mathrm{N}), 1.40$ (m, $72 \mathrm{H}, \mathrm{C}-\left(\mathrm{CH}_{3}\right)_{3}$ e $\left.\mathrm{CH}-\mathrm{CH}_{3}\right) .{ }^{13} \mathrm{C} \mathrm{NMR}\left(\mathrm{CDCl}_{3}\right): 172.0$ (s), 167.6 (s), 154.9 (s), 136.4 (s), 128.38 (d), $80.1(\mathrm{~s}), 75.5$ (d), 74.1 (d), $52.4(\mathrm{t}), 50.5$ (t), 49.2 (d), 28.3 (q), 18.23 (q). Anal. calcd. for $\mathrm{C}_{69} \mathrm{H}_{105} \mathrm{~N}_{9} \mathrm{O}_{27}$ (1492.63): C 55.52, H 7.09, N 8.44. Found C 55.80, H 7.32, N 8.66 \%. 
Triamide (1b). $40 \%$ yield. $\mathrm{R}_{\mathrm{f}}\left(\mathrm{CH}_{2} \mathrm{Cl}_{2}, \mathrm{MeOH} 20: 1\right)=0.55 .[\alpha]_{\mathrm{D}}{ }^{20}=-0.8\left(\mathrm{c}=1.00, \mathrm{CHCl}_{3}\right) . \mathrm{IR}$ $\left(\mathrm{CHCl}_{3}\right): 3443,2977,1752,1708,1634,1152 \mathrm{~cm}^{-1} .{ }^{1} \mathrm{H} \mathrm{NMR}\left(\mathrm{CDCl}_{3}\right): 7.7$ (s, 3H, aromatic core $\mathrm{H}), 7.20(\mathrm{~m}, 30 \mathrm{H}, \mathrm{Ph}), 5.05(\mathrm{~m}, 6 \mathrm{H}, \mathrm{N}-H), 4.86(\mathrm{~m}, 6 \mathrm{H}, \mathrm{CHO}), 4.46(\mathrm{~m}, 6 \mathrm{H}, H \mathrm{H}-\mathrm{Bn}), 3.60(\mathrm{~m}$, 6H, H-CH-N), 3.38 (m, 6H, H-CH-N), 3.02 (m, 12H, CH-CH $-\mathrm{Ph}), 1.42\left(\mathrm{~s}, 27 \mathrm{H}, \mathrm{C}-\left(\mathrm{CH}_{3}\right)_{3}\right), 1.37$ (s, 27H, C-( $\left.\left.\mathrm{CH}_{3}\right)_{3}\right) .{ }^{13} \mathrm{C} \mathrm{NMR}\left(\mathrm{CDCl}_{3}\right): 170.7$ (s), 167.4 (s), 154.8 (s), 136.3 (s) 135.5 (s), 129.2 (d), 128.7 (d), 128.3 (d), 127.3 (d), 80.2 (s), 75.3 (d), 73.9 (d), 54.7 (d), 52.2 (t), 50.4 (t), 38.8 (t), 28.3 (q). Anal. calcd for $\mathrm{C}_{105} \mathrm{H}_{129} \mathrm{~N}_{9} \mathrm{O}_{27}$ (1949.22): C 64.70, H 6.67, N 6.47. Found C $64.47 \mathrm{H}$ $6.81 \mathrm{~N} 6.13 \%$.

Triamide (1c). 57\% yield. $\mathrm{R}_{\mathrm{f}}$ (ethyl acetate petroleum ether $\left.3: 1\right)=0.62 .[\alpha]_{\mathrm{D}}{ }^{20}=-18.1(\mathrm{c}=$ 1.00, $\left.\mathrm{CHCl}_{3}\right)$ IR $\left(\mathrm{CHCl}_{3}\right): 3449,2980,1706,1629,1157 \mathrm{~cm}^{-1} .{ }^{1} \mathrm{H}$ NMR $\left(\mathrm{CDCl}_{3}\right): 7.86(\mathrm{~s}, 3 \mathrm{H}$, aromatic core $\mathrm{H}), 5.23(\mathrm{~m}, 12 \mathrm{H}, \mathrm{CHO}-$ and $\mathrm{N}-\mathrm{H}), 4.87(\mathrm{~m}, 6 \mathrm{H}, \mathrm{N}-\mathrm{H}), 4.4-3.9(\mathrm{~m}, 12 \mathrm{H}), 3.85-$ $3.60\left(\mathrm{~m}, 6 \mathrm{H}, \mathrm{CH}_{2} \mathrm{~N}\right.$ anello), $3.10\left(\mathrm{~m}, 12 \mathrm{H}, \mathrm{CH}_{2} \mathrm{NH}\right), 2.00-1.00\left(144 \mathrm{H},-\mathrm{CH}_{2}-\right.$ and $\left.-\mathrm{C}\left(\mathrm{CH}_{3}\right)_{3}\right) .{ }^{13} \mathrm{C}$ NMR $\left(\mathrm{CDCl}_{3}\right): 171.7$ (s), 167.5 (s), 156.1 (s), 155.4 (s), 136.3 (s), 128.5, (d), 80.0 (d), 79.1 (d), $75.6(\mathrm{~s}), 74.3(\mathrm{~s}), 53.4(\mathrm{~d}), 52.4(\mathrm{t}), 50.4(\mathrm{t}), 39.9(\mathrm{t}), 31.79(\mathrm{t}), 29.6(\mathrm{t}), 28.46(\mathrm{q}), 28.3(\mathrm{q}), 22.5$ (t). Anal. calcd. for $\mathrm{C}_{117} \mathrm{H}_{195} \mathrm{~N}_{15} \mathrm{O}_{39}$ (2435.90): C 57.69, H 8.07, $\mathrm{N}$ 8.62. Found. C 57.86, H 8.21, N $8.39 \%$.

\section{General procedure of synthesis of amide 6 and diamide 7}

A solution of the amine 5a $(1 \mathrm{mmol}, 446 \mathrm{mg})$ in dry $\mathrm{CH}_{2} \mathrm{Cl}_{2}(12 \mathrm{~mL})$ was added with DMAP (20 $\mathrm{mg}, 0.16 \mathrm{mmol}$ ) and DIPEA (4 mmol, $0.7 \mathrm{~mL})$. The solution was cooled in an ice bath and added with benzoyl chloride ( $1 \mathrm{mmol}, 1$ eq., $140 \mathrm{mg}$ ) or terephtaloyl chloride $(0.5 \mathrm{mmol}, 1 \mathrm{eq} ., 101 \mathrm{mg})$. The solution was stirred under inert atmosphere for $2 \mathrm{~h}$. The solution was then diluted with $\mathrm{CH}_{2} \mathrm{Cl}_{2}(50 \mathrm{~mL})$ and washed with $0.5 \mathrm{M} \mathrm{HCl}$, saturated $\mathrm{NaHCO}_{3}$ and finally with brine. The organic phase was dried with $\mathrm{Na}_{2} \mathrm{SO}_{4}$ and concentrated to afford the crude reaction mixture which was purified by passage on a short pad of silica gel.

Amide (6). 93\% yield. $\mathrm{R}_{\mathrm{f}}$ (ethyl acetate petroleum ether $\left.1: 1\right)=0.34 .[\alpha]_{\mathrm{D}}{ }^{20}=-7.22(\mathrm{c}=1.02$, $\left.\mathrm{CHCl}_{3}\right)$. IR $\left(\mathrm{CHCl}_{3}\right): 3440,2983,1749,1708,1627,1154 \mathrm{~cm}^{-1} .{ }^{1} \mathrm{H}$ NMR $\left(\mathrm{CDCl}_{3}\right): 7.55-7.3(\mathrm{~m}$, 5H, Ph), 5.2 (bs, 2H, CHO-), 4.40-4.00 (m, 3H, $\mathrm{H}-\mathrm{CH}-\mathrm{NBz}$ and $\left.\mathrm{CH}_{3}-\mathrm{CH}-\mathrm{NH}\right), 3.84$ (m, $2 \mathrm{H}, \mathrm{H}-$ $\mathrm{CH}-\mathrm{N}), 3.62(\mathrm{~d}, \mathrm{~J}=11.5 \mathrm{~Hz}, 1 \mathrm{H}, \mathrm{H}-\mathrm{CH}-\mathrm{N}), 1.40\left(\mathrm{~m}, 24 \mathrm{H}, \mathrm{C}-\left(\mathrm{CH}_{3}\right)_{3}\right.$ and $\left.\mathrm{CH}-\mathrm{CH}_{3}\right) .{ }^{13} \mathrm{C}$ NMR $\left(\mathrm{CDCl}_{3}\right): 172.2$ (s), 170.1 (s), 155.1 (s), 135.7 (s), 130.4 (d), 128.5 (d), 127.3 (d), 80.1 (s), 75.4 (d), 74.2 (d), 52.5 (t), 50.0 (t), 49.2 (d), 28.2 (q), 18.0 (q). Anal. calc. for $\mathrm{C}_{27} \mathrm{H}_{39} \mathrm{~N}_{3} \mathrm{O}_{9}$ (549.62): C 59.00, H 7.15, N 7.64. Found C 59.20, H 7.30, N 7.29\%.

Diamide (7). 68\% yield. $\mathrm{R}_{\mathrm{f}}$ (ethyl acetate petroleum ether $\left.5: 1\right)=0.43 .[\alpha]_{\mathrm{D}}{ }^{20}=-7.4(\mathrm{c}=1.00$, $\left.\mathrm{CHCl}_{3}\right)$. IR $\left(\mathrm{CHCl}_{3}\right): 3446,2982,1750,1708,1629,1153 \mathrm{~cm}^{-1} .{ }^{1} \mathrm{H} \mathrm{NMR}\left(\mathrm{CDCl}_{3}\right): 7.59(\mathrm{~s}, 4 \mathrm{H}$, $\mathrm{Ph}), 5.28$ (m, 2H, CHO-), 5.18 (m, 2H, CHO-), 4.93 (m, 4H, N-H), 4.4-4.0 (m, 6H, H-CH-N and $\left.\mathrm{CH}-\mathrm{CH}_{3}\right), 4.0-3.5(\mathrm{~m}, 6 \mathrm{H}, \mathrm{H}-\mathrm{CH}-\mathrm{N}), 1.4\left(\mathrm{~m}, 48 \mathrm{H}, \mathrm{C}-\left(\mathrm{CH}_{3}\right)_{3}\right.$ e $\left.\mathrm{CH}-\mathrm{CH}_{3}\right) .{ }^{13} \mathrm{C} \mathrm{NMR}\left(\mathrm{CDCl}_{3}\right)$ : 172.2 (s), 169.1 (s), 155.1 (s), 137.6 (s), 127.6 (d), 80.2 (s), 75.3 (d), 74.2 (d), 52.5 (t), 50.1 (t), 49.2 (d), 28.2 (q), 18.3 (q). Anal. calcd. for $\mathrm{C}_{48} \mathrm{H}_{72} \mathrm{~N}_{6} \mathrm{O}_{18}$ (1021.13): C 56.46, H 7.11, N 8.23. Found C 56.71 H 7.24 N 8.36. 


\section{Acknowledgments}

Degussa A.G. is gratefully acknowledged for a generous gift of enantiopure $(3 S, 4 S)$ - $N$-benzyl3,4-dihydroxypyrrolidine (2)

\section{References}

1. Molecular Recognition: Chemical and Biochemical Problems Roberts S. M. Ed., RSC, Special Publication n. 78, 1990.

2. (a) Gutsche, C. D. Calixarenes, Monographs in Supramolecular chemistry no. 1, RSC: Cambridge, 1989. (b) Diederich, F. Cyclophanes, Monographs in Supramolecular chemistry no. 2, RSC: Cambridge 1991. (c) Supramolecular control of structure and reactivity, Hamilton, A.D., Ed.; Wiley: Chichester, 1996. (d) Vogtle, F. Supramolecular Chemistry, an Introduction, Wiley: Chichester, 1991

3. Rebek, J. Jr. Top. Curr. Chem. 1988, 149, 189.

4. (a) Jorgensen, M.; Krebs, F. C. Tetrahedron Lett. 2001, 42, 4717. (b) Azumaya, I.; Kagechika, H.; Yamaguchi, K.; Shudo, K. Tetrahedron 1995, 51, 5277. (c) in solution phase: Tor, Y.; Libman, J.; Shanzer, A.; Felder, C. E.; Lifson, S. J. Am Chem. Soc. 1987, 109, 749 (d) Armstrong, S. K.; Clunas, S.; Muir, K. W. Synthesis 1999, 993.

5. (a) Moberg, C. Angew. Chem., Int. Ed. 1998, 37, 248. (b) Kraft, A.; Osterodt, F.; Frohlic, R. J. Org. Chem. 1999, 64, 6425.

6. Bowles, P.; Clayden, J.; Helliwell, M.; McCarthy, C.; Tomkinson, M.; Westlund, N. J. Chem. Soc., Perkin Trans. I 1997, 2607.

7. Cicchi, S.; Goti, A.; Rosini, C.; Brandi, A. Eur. J. Org. Chem. 1998, 2591.

8. Pc Spartan Pro Suite (wavefunction, Inc., 18401 Von Karman, Suite 370, Irvine California, 92612.

9. Wilcox, C. S.; Cowart, M. D. Tetrahedron Lett. 1986, 46, 5563.

10. Connors, K. A. Binding Constants; Wiley Interscience: New York, 1987. 